\title{
STUDY OF STRENGTH CHARACTERISTICS OF CRUSHED GLASS USED AS FINE AGGREGATE IN CONCRETE
}

\author{
B.V. Kavyateja ${ }^{1}$, P. Narasimha Reddy ${ }^{2}$, U.Vamsi Mohan ${ }^{3}$ \\ ${ }^{1}$ Department of Civil Engineering, MJR College of Engineering \& Technology \\ Email: kavyateja2014@gmail.com \\ ${ }_{2}^{2}$ Department of Civil Engineering, Gurunanak Institutions Technical Campus Hyderabad. \\ Email: aryancivil130@gmail.com \\ ${ }^{3}$ Department of Civil Engineering, Sri Venkateswara College of Engineering and Technology \\ Email:vamsiu1968@gmail.com
}

\begin{abstract}
The study provides details regarding exploratory examination on the suitability of squashed glass as partially replaced for fine total in solid generation. The control blending proportion of 1: 1.5: 3 grouped by volume with water-bond proportion of 0.5 were utilized. The rate substitution differed from $0 \%$ to $40 \%$ at an interim of $10 \%$. The slump test was utilized to survey the workability of the fresh concrete. The compressive qualities of cured solid $3 D$ shapes of sizes $150 \mathrm{~mm} \times 150 \mathrm{~mm} \times 150 \mathrm{~mm}$ were assessed at 3days, 7 days, 28 days, 56 days, and 90 days. The split tensile strength of concrete cube of size 150mm diameter and $300 \mathrm{~mm}$ length were evaluated at age of curing 28 days. To obtain the test results the workability is increased, compressive strength is increased up to 20\% replacement level and at 30\%, 40\% replacement level it goes to decreasing, and Split tensile strength is slightly decreasing as compared to normal concrete.
\end{abstract}

Keywords: Concrete, Aggregates, Crushed Glass, Compressive Strength, Split Tensile Strength.

\section{INTRODUCTION}

Glass is a straightforward material created by softening a blend of materials, for example, silica, pop fiery debris, and $\mathrm{CaCO} 3$ at high temperature took after by cooling where cementing happens without crystallization. Glass is broadly utilized as a part of our lives through fabricated items, for example, sheet glass, containers, dish sets, and vacuum tubing In the wake of utilizing of these glass items they are dumped into landfill destinations, the area gets contaminated because of these glass items are not biodegradable materials. This prompts natural irregularity. In our general public waste item substitution is a gigantic potential and in this paper waste glass utilized as a part of the solid development division. The smashed glass or cullet, if legitimately measured and handled, can show attributes like that of rock or sand are utilized as a part of development segment. At the point when utilized as a part of development applications, waste glass must be smashed and screened to create a suitable configuration degree. Glass is crushed into loss angels abrasion apparatus. Glass crushing equipment in construction sector is normally used to reduce the size of the glass and it is similar to rock crushing equipment. The devastating hardware utilized is commonly littler and utilizes less vitality than typical total or shake squashing gear.

Using of crushed waste glass in concrete construction sector is to save the lot of energy, human health problems and the expanding familiarity with glass reusing speeds up spotlight on the utilization of waste glass with various structures in different fields. A few studies have demonstrated that waste glass that is pulverized and screened is a solid, protected and conservative distinct option for sand utilized as a part of cement. When crushed glasses are used in concrete works mainly two advantageous are there; first, it will be environment amicable, second, it will use waste setup of valuable and generally costlier regular assets.

In order to reduce the waste glass materials in the earth and to make the concrete industry sustainable to replace the waste glass as natural resources is one of the best approaches. A colossal amount of waste glass is produced all around the globe. In India, $0.7 \%$ of aggregate urban waste created contains glass. UK produces more than three million tons of waste glass every year. Liang, Hong ; Zhu, Huiying, Ewan A. suggested that the effective utilization of coloured glass aggregates in a range of architectural concretes and their properties tests [1]. Shayan and $\mathrm{Xu}$ reported fine glass powder for consolidation into cement up to $30 \%$ as a pozzolanic material smothered the ASR [2].

The most generally utilized fine total for the making of cement is the characteristic sand mined from the riverbeds. In any case, the accessibility of waterway sand for the readiness of cement is turning out to be rare because of the over the top non-logical techniques for mining from the riverbeds, bringing down of water table, sinking of the scaffold docks, and so on are getting to be regular treats. Due to ASR (Alkali Silica Reaction) waste glass used as fine aggregate in concrete creates a problem in concrete. The response between Portland concrete and totals shapes 
antacid silica gel. This gel is inclined to be swelling. It assimilates water and the volume of the gel increments. Under repression by bond framework and total, the swelling of the ASR gel creates hydrostatic weight. In the event that inside weight is surpasses and the response proceeds with it will frame the breaks and the rigidity of the framework to the receptive total particles.

In this examination, fine totals were somewhat supplanted by smashed glass as $10 \%, 20 \%, 30 \%$ and $40 \%$ by weight. Solid examples were tried for compressive quality, part elasticity, and light weight nature for various waste glass rates. The outcomes acquired were contrasted and after effects of typical M-20 solid blend and it was found that most extreme increment in compressive quality happened for the solid blend containing $20 \%$ waste glass as fine total. With expansion in waste glass content, the part elasticity will be diminished. Thickness of cement diminished with expansion in waste glass content hence making solid light weight in nature.

\section{EXPERIMENTAL PROCEDURE}

\subsection{Concrete Composite Materials}

To make the concrete the raw materials used for this study is to be Ordinary Portland Cement of 53 grade, fine aggregate, coarse aggregate, crushed glass and water.

\subsubsection{Cement}

Ordinary Portland Cement of 53grade was used in this work and it is stored in the air light container. The cement used in this work is fresh i.e., used within three months of manufacture and it should satisfy the requirement of IS 12269. The properties of cement are determined as per the IS 4031 method of test and results are tabulated in the chart1.

\subsubsection{Fine aggregate}

Fine aggregate or sand is distinguished from crushed stones by the size of grains or particles. Normally fine aggregate used to prepare the concrete is river sand confirming zone II. It should satisfy the requirement of IS 383-1970. Its size should be passing through IS sieve $4.75 \mathrm{~mm}$ and retaining on $150 \mu$ with specific gravity of 2.6.

\subsubsection{Coarse aggregate}

Coarse total are the squashed stone utilized for the making concrete as a part of this study. The state of the coarse total utilized is rakish. The extent of the coarse total was utilized as going through IS strainer $20 \mathrm{~mm}$ and holding on $4.75 \mathrm{~mm}$ with particular gravity of 2.7 .

\subsubsection{Crushed glass}

The waste glass was gathered from the garbage shops in close Chittoor comprising of glass containers (regular glass sort). They are squashed into Los Angeles scraped area mechanical assembly and after that sieved through IS sifter
$4.75 \mathrm{~mm}$ and holding on $150 \mu$. The particular gravity of pulverized glass is to be 2.42 . The chemical composition of glass is displayed in table 2

\subsubsection{Water}

In this investigation the water used for casting and curing of all specimens is to be potable water in nearby Chittoor. The quality of water was found to be satisfying the requirement of IS 456-2000.

\subsection{Mix Proportion and production of concrete cubes}

The concrete mix design is done in accordance with IS: 10262. Mix design was used as $\mathrm{M}_{20}$ to prepare the concrete. The water cement ratio was used as 0.5 . The casting of the cubes was done in concrete steel moulds of $150 \mathrm{~mm} \mathrm{x}$ $150 \mathrm{~mm} \times 150 \mathrm{~mm}$ similarly cylinders also casted in steel moulds of $150 \mathrm{~mm}$ dia and $300 \mathrm{~mm}$ length. First the steel moulds are cleaned and apply oil properly in to the moulds for easy removal of hardened concrete cubes and cylinders. The concrete cubes and cylinder are prepared by using crushed glass as partial replacement of fine aggregate by using mix proportion of $1: 1.5: 3$. The casting of cubes and cylinders are removed from the mould after 24 hours then they were immersed into the curing tank before the testing like 3,7,14,28,56,90 days in order to obtain the strength of concrete. Before testing the cubes and cylinders are removed from the curing tank and they are left in the open air before crushing. In this investigation the compressive strength and split tensile strength was finding out by using universal testing machine of 40 tons.

\section{TEST RESULTS AND DISCUSSIONS}

\subsection{Workability}

The workability of all control blends are controlled by utilizing droop test through droop metallic mold. The workability of cement clumps for various rate substitution of squashed glass utilizing droop test is appeared as a part of Table 3.This droop test is performed by 1199-1959[11]. The distinction in level between the stature of the mold and that of most elevated purpose of the died down cement was measured and reported as droop. The workability of solid increment with expansion in the rate substitution of fine total by smashed glass. Because of these squashed glass particles ingests less water when contrasted with sand. in this way, workability of solid blend is expanded.

\subsection{Compressive strength}

The solid 3D squares were tried according to IS 516-1959. The test was directed in pressure testing machine. The heap was connected until the disappointment of the example. The most extreme burden connected to the example until disappointment was recorded and to compute the compressive quality. The compressive qualities of solid 3D square for various rates of pounded glass supplanted as sand are introduced in Tables 4 for solid blending proportion 
1:1.5:3.The impacts of substitution of squashed glass as fine total the compressive qualities of the solid shapes are appeared in chart.1. It can be seen that the compressive quality is expanded up to $20 \%$ substitution of smashed glass as fine total and further $30 \%$ and $40 \%$ substitution level the compressive quality is diminished. The purpose behind diminishing the quality is to be the rate of pounded glass content increments in the solid, the particular surface zone increments, in this manner it requires more concrete glue to security adequately with the pulverized glass however here the bond content continues as before, the holding is consequently deficient. Quality depends to a vast degree on great holding between the bond glue and the totals.

\subsection{Split Tensile Strength}

As per IS specifications IS 5816:1999 Split tensile test were conducted. The cylinders of size $150 \mathrm{~mm}$ diameter and 300 $\mathrm{mm}$ length are tested for tensile strength. The split tensile strength values are decreased by increasing the crushed glass replaced as sand into the concrete. Its strength is inversely proportional to replacement of crushed glass. The split tensile strength values are tabulated in table 5.

To find split tensile strength following equation has used. Chart 2 shows the testing of split tensile test.

Split Tensile Strength=2P/(ПDL)

Where

$\mathrm{P}=$ Split tensile load

$\mathrm{D}=$ Diameter of the cylinder

$\mathrm{L}=$ Length of the cylinder

Table-1: Physical properties of cement

\begin{tabular}{|c|c|}
\hline Properties & Values \\
\hline Cement & 53 grade \\
\hline Fineness & $6 \%$ \\
\hline Normal consistency & $34 \%$ \\
\hline Initial setting time & $42 \mathrm{~min}$ \\
\hline Final setting time & $320 \mathrm{~min}$ \\
\hline Specific gravity & 3.13 \\
\hline
\end{tabular}

Table-2: Chemical Composition of Crushed glass

\begin{tabular}{|c|c|}
\hline Components & Percentage (\%) \\
\hline Silica $\left(\mathrm{SIO}_{2}\right)$ & 70.4 \\
\hline Alumina $\left(\mathrm{AL}_{2} \mathrm{O}_{3}\right)$ & 1.9 \\
\hline Iron oxide $\left(\mathrm{Fe}_{2} \mathrm{O}_{3}\right)$ & 1.2 \\
\hline Magnesium oxide $(\mathrm{Mgo})$ & 10.3 \\
\hline Sodium oxide $\left(\mathrm{Na}_{2} \mathrm{O}\right)$ & 14.0 \\
\hline Potassium oxide $\left(\mathrm{K}_{2} \mathrm{O}\right)$ & 0.4 \\
\hline
\end{tabular}

Table-3: Workability at 28 days age of concrete cubes by using slump cone test

\begin{tabular}{|c|c|}
\hline Crushed glass & Slump cone values $(\mathrm{cm})$ \\
\hline $0 \%$ & 25 \\
\hline $10 \%$ & 28 \\
\hline $20 \%$ & 29 \\
\hline $30 \%$ & 30 \\
\hline $40 \%$ & 32 \\
\hline
\end{tabular}

Table-4: Compressive Strength of concrete cubes at different percentage of crushed glass replaced as sand

\begin{tabular}{|c|c|c|c|c|c|}
\hline $\begin{array}{c}\text { Crushed glass } \\
\text { percentage } \\
(\%)\end{array}$ & $\begin{array}{c}3 \\
\text { days }\end{array}$ & $\begin{array}{c}7 \\
\text { days }\end{array}$ & $\begin{array}{c}28 \\
\text { days }\end{array}$ & $\begin{array}{c}56 \\
\text { days }\end{array}$ & $\begin{array}{c}90 \\
\text { days }\end{array}$ \\
\hline 0 & 17.5 & 21.7 & 33.8 & 37.54 & 42.1 \\
\hline 10 & 24 & 25.77 & 35.6 & 44.4 & 45.6 \\
\hline 20 & 24.88 & 27.99 & 38.4 & 45.84 & 45.9 \\
\hline 30 & 23.9 & 24.9 & 34.25 & 36.7 & 37.1 \\
\hline 40 & 23.12 & 20.32 & 32.54 & 35.01 & 35.3 \\
\hline
\end{tabular}

Table-5: Split tensile strength of concrete cubes at 28 days of different percentage of crushed glass replaced as sand.

\begin{tabular}{|c|c|}
\hline $\begin{array}{c}\text { Crushed glass percentage } \\
(\%)\end{array}$ & $\begin{array}{c}\text { Split tensile strength at 28 } \\
\text { days N/mm }\end{array}$ \\
\hline 0 & 2.68 \\
\hline 10 & 2.4 \\
\hline 20 & 2.2 \\
\hline 30 & 2.12 \\
\hline 40 & 2.0 \\
\hline
\end{tabular}

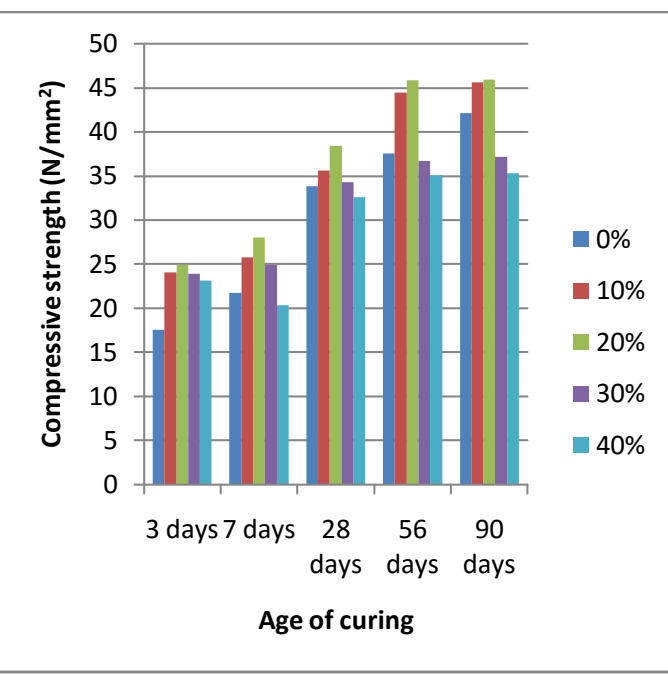

Chart-1: Compressive strength for different ages by using different percentages of crushed glass as sand into the concrete.

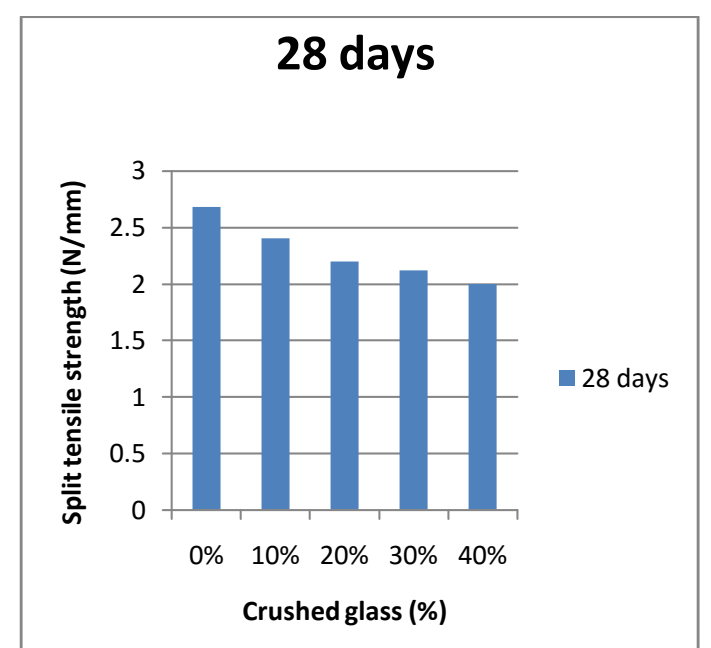

Chart-2: Split tensile strength at 28 days age for different percentage of crushed glass as sand into the concrete 


\section{CONCLUSIONS}

Based on the investigation and experimental results, the following conclusions can be made

1. There exist high potential for the use of crushed glass as fine aggregate into the concrete for the saving of natural aggregate.

2. With increasing of crushed glass particles into the concrete the workability should be increased gradually as compared to normal concrete.

3. Crushed glass replaced as fine aggregate into the concrete the compressive strength should be increased up to $20 \%$ replacement level and after $30 \%$ and $40 \%$ replacement level it goes to decreasing.

4. The split tensile strength should be decreased gradually at increasing of crushed glass replaced as sand into the concrete.

\section{REFERENCES}

[1]. Laing Hong, zhu, Huiying studies on "use of waste glass as aggregate in concrete".

[2]. A.Shayan, and A. Xu, "Value - Added Utilization of waste glass in Concrete," Cem. Concr. Res., vol. 34, no.1, pp. 81-89, May 2004.

[3]. Asoka Pappu, MohiniSaxena, and Shyan R. Asolekar, "Solid Waste Generation In India And Their Recycling Potential In Building Materials", Regional Research Institute (CSIR) and IIT Bombay, India.

[4].P Turgut and E.S. Yahlizade, "Research into Concrete Blocks with Waste Glass", International Journal of Civil and Environmental Engineering 1:4 2009.

[5]. I.B.Topcu and M. Canbaz, "Properties of Concrete containing waste glass", Cement and Concrete Research,vol. 34, pp. 267-274, Feb. 2004.

[6]. Job Thomas, "Utilization of quarry powder as a substitute for the river sand in concrete", J. Struct. Eng., vol.32, no.5, pp. 401-407, January 2006.

[7]. Indian standard specification IS 12269 (1987): 53 grade ordinary Portland cement [CED 2: cement and concrete].

[8]. Indian standard institution IS 383 (1970): specification for coarse and fine aggregate from natural sources for concrete.

[9]. IS 10262:2009 Code for Concrete Mix Proportion, Bureau of Indian Standards, New Delhi, India.

[10].IS 456-2000 Code of practice for plain and reinforced concrete structure, Bureau of Indian Standards, New Delhi, India.

[11].M.S. Shetty, (2004), Concrete technology, Chand S. and Co Ltd, India. 